\title{
FGF1 Gene Amplification
}

National Cancer Institute

\section{Source}

National Cancer Institute. FGF1 Gene Amplification. NCI Thesaurus. Code C148112.

A molecular genetic abnormality indicating the presence of multiple copies of the FGF1 gene. 